\title{
Review on Productive and Reproductive Performance of Different Genetic Group of Chicken in Ethiopia
}

\author{
Maticha Korato ${ }^{1, *}$, Teramaj Abebe ${ }^{2}$, Bayesa Tolasa ${ }^{3}$ \\ ${ }^{1}$ Department of Animal Science, Bonga University, Bonga, Ethiopia \\ ${ }^{2}$ Department of Animal Science, Mekdela Amba University, Mekdela, Ethiopia \\ ${ }^{3}$ Department of Animal Science, Werabe University, Werabe, Ethiopia
}

Email address:

matichakorato2008@gmail.com(M. Korato)

${ }^{*}$ Corresponding author

\section{To cite this article:}

Maticha Korato, Teramaj Abebe, Bayesa Tolasa. Review on Productive and Reproductive Performance of Different Genetic Group of Chicken in Ethiopia. American Journal of Bioscience and Bioengineering. Vol. 9, No. 5, 2021, pp. 147-150.

doi: 10.11648/j.bio.20210905.14

Received: March 4, 2021; Accepted: September 2, 2021; Published: October 30, 2021

\begin{abstract}
This review paper was conducted with the aim of reviewing productive and reproductive performance of different chicken breeds in Ethiopia. In Ethiopia, chicken production plays a role as a prime supplier of eggs and meat in rural and urban area and as a source of income. As indicated current review results, indigenous chicken breeds had low productive and reproductive performance than exotic breeds. The average age at first egg ranges 6-12 months for indigenous chicken. Their egg production potential ranges 30-60 eggs per year per hen with average egg weight of 38g under village management conditions; while under intensive system they produce 80-100 eggs per year per hen. Average hatchability of eggs was $80 \%$ for indigenous chickens. On the other hand, performance of exotic differs from indigenous chickens. Average age for first egg was 5 months for exotic chicken breeds under intensive management system in Ethiopia. Exotic breeds of chicken kept under intensive condition produce around 250 eggs /year/hen with average egg weight of 50-60g; while under village production system it may go down up to 150 with average weight of egg $44 \mathrm{~g}$. Average hatchability of eggs was around $70 \%$ for exotic chickens in Ethiopia. Generally, this review work recommended cross breeding should be used to combine these different performances of exotic and indigenous chickens so as to create crossbreed chickens having resistance to harsh environment of Ethiopia.
\end{abstract}

Keywords: Chickens, Exotic, Indigenous, Performance, Ethiopia

\section{Introduction}

Recent estimates put Ethiopian chicken population at about 57 million of which $78.85,12.02$, and $9.11 \%$ were reported to be indigenous, exotic, and crossbreeds, respectively CSA [1]. From the total population of chicken in Ethiopia, 99\% are raised under the traditional back yard system of management, while $1 \%$ is under intensive management system. The traditional poultry production system is characterized by small flock sizes, low input and output and periodic devastation of the flock by disease [2]

In report of many researchers the main problem of indigenous chickens in Ethiopia is that they are poor producer of egg and meat [3, 4]. But even if they show low productivity, they are well adapted to the tropics, resistant to poor management, feed shortages and tolerate some of the most common diseases and parasites. On the other hand, exotic chickens produce more number of eggs and more meat than the indigenous chicken breeds, but climate is a great challenge.

In Ethiopia, chicken production plays a great role as a prime supplier of eggs and meat in rural and urban area and as a source of income, especially to women; so role of poultry in Ethiopia has been becoming more important from time to time [5]. This great role of poultry made different attempts to take place to introduce different high performance exotic poultry breeds to small holder farming 
systems of Ethiopia through different organizations [6].

Generally, there are many researches that have been conducted on performances of different genetic group chickens breeds in different Ethiopia, but there is no comprehensive review work done on their performance comparatively. Therefore, reviewing productive and reproductive performance of these different genetic groups of chicken is a prioritized issue in the country. Therefore, the present study briefly reviewed productive and reproductive performance of different genetic group chickens to deliver synthesized information for beneficiaries.

\section{Literature Review}

\subsection{Performance of Indigenous Chicken Breeds in Ethiopia}

\subsubsection{Growth Performance of Indigenous Chickens}

Day old chicks of different populations of indigenous chicken measures live weight of $27.3 \mathrm{~g}$ per chick $[7,8]$. Nigussie [9] reported adult live body weight of the different populations of indigenous local chickens $1.6 \mathrm{~kg}$ for male and $1.3 \mathrm{~kg}$ for female chickens. As Bogale [8] indicated the meat production ability of indigenous chicken was limited due to less growth performance indigenous chickens. Indigenous male chickens reach $1.5 \mathrm{~kg}$ live weight at 6 months of age and female chickens about $30 \%$ less [8]. Study of Abebe [10] found that the indigenous chicken in Eastern Ethiopia attained $71.5 \%$ of the body weight of White Leghorn at 6 months of age. Solomon [11] reported that there was no difference between White Leghorn and indigenous chickens raised under scavenging condition in mean daily body weight gain at 2 months of age. Bekele et al. [12] reported $28.6 \mathrm{~g}$, $294 \mathrm{~g}$ and $638.2 \mathrm{~g}$ day old chick, eight-week-old chick and hens' mature body weight for local Sidancho respectively, under on farm management from Hawassa. While the same authors reported $30.5 \mathrm{~g}$ day old chick body weight and $788.8 \mathrm{~g}$ mature body weight of hen for the above indigenous type chicken under on station management. As reported by Nigussie et al. [13], cock and hen of horro indigenous chicken weight at age of 16 weeks were $701.10 \mathrm{~g}$ and $572.7 \mathrm{~g}$, respectively.

\subsubsection{Age at First Egg of Indigenous Chickens}

The age in which local chickens reach at age at first egg laying is variable. This variation could be attributed to genotype, management and season [8]. According to Habte et al. [14] mean age at first egg laying of indigenous pullets in the Nole Kabba wereda of Western Wollega was 7.02 months. This was also comparable with the finding of Mekonnen [15] who reported that the mean age at first egg laying of young indigenous pullets in three districts of SNNPRS was 7.7 months. Addisu et al. [16] also reported that the age at first egg laying of local chickens in North Wollo zone of Amhara region was 6.6 months. As reported Nigussie et al. [13], age at first egg for horro indigenous chicken was 6.3 months. However, Halima [7] reported shorter average age at first egg laying of indigenous young pullets in North West Ethiopia which were 5 months.

\subsubsection{Egg Production Performance of Indigenous Chickens}

In Ethiopia the total $99 \%$ of egg production is contributed by local chickens [17]. According to Kidane [18] the average annual egg production potential of indigenous chicken at Wolita agricultural development unit was ranged between 3060 eggs under village free range production systems. At Asela, Brannang and Pearson [19] discovered that the average egg production of local birds was 34 eggs/hen/year with average egg weight of $38 \mathrm{~g}$. However, at station numbers of eggs were enhanced to 80-100 with improved environmental systems [20]. According to Bogale [8] the average number of eggs incubated/hen was 13 . Under the present condition laying hen needs about 120-130 days to accomplish one production cycle that is 40-50 days of laying, 21 days of incubation and 60 days of brooding chicks. Generally, a hen lays about 36 eggs in three clutches and 12 to 13 eggs per each clutch per year [8]. Report of CSA [21], indicated the average length egg-laying period/hen estimated 23 days.

\subsubsection{Hatchability of Indigenous Chicken Eggs}

As reported by Tadelle \& Ogle [22], Halima [7] and Habte et al. [12], the average hatchability rate of eggs of indigenous chickens $81.11 \%$ (ranging from $44-100$ ), $60.7 \%$ to $82.1 \%$, and $82.74 \%$ in Central highlands of Ethiopia, North Western of Ethiopia and Nole Kabba wereda of Western Wollega, respectively. Nebiyu et al. [23], Solomon et al. [24] and Wondu et al. [25] found that average egg hatchability of local chickens in Halaba woreda of southern Ethiopia, Metekel Zone of North West Ethiopia and North Gondar Amhara regional state were $83.72 \%, 84.74 \%$ and $87.29 \%$, respectively. Worku et al. [26] also reported slightly similar figure on the egg hatchability of local chickens in West Amhara region of Ethiopia was $79.1 \%$. On the other hand, Meseret [27] reported the lower average hatchability result of indigenous chickens in Gomma woreda (22\%).

\subsection{Performance of Exotic Chicken Breeds in Ethiopia}

\subsubsection{Age at First Egg and Sexual Maturity of Exotic Chickens}

Sexual maturity of White Leghorn under intensive and extensive management ranges from 149-169 days [28]. According to Tomas et al. [29], mean sexual maturity age were 146 and 163.8 days for BB under intensive and back yard production system, respectively in Mekele. Desalew et al. [30] reported mean age at first laying were 160.5, 165.5 and 153.3 days for $\mathrm{IB}, \mathrm{BB}$ and $\mathrm{KK}$, respectively under village production system in East Shewa. In contrast, Abraham and Yayneshet [31] reported higher age at first egg 231, 239 and 245 days for Fayoumi, RIR and White Leghorn exotic chicken breeds respectively, under farmers' production system in central Tigray.

\subsubsection{Egg Production Performance of Exotic Chickens}

There are many factors that can adversely affect egg 
production of chickens. It can be affected by type of breed, feed consumption both in quality and quantity, water intake, intensity and duration of light received, parasite infestation, diseases, management and environmental factors even within the same breeds [32]. Different authors reported the effect of breed on egg production. According to Alganesh et al. [33] exotic breeds of chicken kept under intensive condition produce around $250 \mathrm{eggs} / \mathrm{year} / \mathrm{hen}$ with average egg weight of 50-56g. Desalew [34] reported 276 eggs form Isa Brown (IB), 266 eggs from Bovan Brown (BB) and 187 eggs from Koekoek $(\mathrm{Kk})$ under village production system in East Shewa per year/hen. But annual egg production reported by Abraham and Yayneshet [31] for the Egyptian Fayoumi, Rhode Island Red and White Leghorn exotic chicken breeds was 156, 185 and 176/hen respectively, under extensive management. Report of Alem [35] indicated average egg production per clutch per hen for RIR was 45.2 in central Tigray. As reported by Geleta et al. [36], egg weight of Fayoumi chicken at Adami Tulu Research center was 44.3g. Abraham and Yayneshet [31] reported weight for egg of Fayoumi (43 g), for Rhode Island Red egg $(52.5 \mathrm{~g})$ and for White Leghorn egg $(52.1 \mathrm{~g})$ in north Ethiopia. Report of Desalew et al. [33] also indicated average egg weight of KK (48.84g), IB (58.75g) and BB $(60.27 \mathrm{~g})$ from East Shewa.

\subsubsection{Hatchability of Exotic Chicken Eggs}

According to Geleta et al. [36] egg produced from Fayoumi chickens under Oromia Agricultural Research Institute had lower hatchability (63.5\%) compared to hatchability reported by Abraham and Yayneshet [31], 67.9\% for Fayoumi and $76.1 \%$ for White Leghorn but higher than for Rhode Island Red (39.3\%) in northern Ethiopia. similarly, Kebede et al. [37] reported eggs collected from White Leghorn under intensive management have higher (78.6$81.4 \%$ ) hatchability.

\section{Conclusion}

Chicken production plays a great role as a prime supplier of eggs and meat in rural and urban area and as a source of income. Indigenous chickens in the tropics are poor producer of egg in steady they adapt to the tropics, resistant to poor management and tolerate disease. On the other hand, exotic chickens produce more number of eggs and meat than the indigenous chicken breeds, but tropical climate is a great challenge. Local male chickens may reach $1.5 \mathrm{~kg}$ live weight at 6 months of age and female chickens about $30 \%$ less. The age in which local chicks reach at age at first egg laying is variable and most researchers reported average age at first egg 6 months. The egg production potential of indigenous chicken reported ranges $30-60$ eggs year ${ }^{-1}$ hen $^{-1}$ with an average of $38 \mathrm{~g}$ egg weight under village management conditions, while they produce around 80-100 eggs year ${ }^{-1}$ hen $^{-1}$ with under intensive managements. The hatchability of eggs of indigenous chickens ranges from 44-100 as reported by different researchers. Sexual maturity of exotic chickens under intensive and extensive management ranges from 149170 days, while under back yard production system more than 170 days. Exotic breeds of chicken kept under intensive condition produce around 250 eggs per year per hen with average egg weight of $56 \mathrm{~g}$. The hatchability of eggs of exotic chickens reported ranges from 40-80 eggs.

The present review indicated that indigenous chickens had low productive and reproductive potential but they can resist harsh environment, diseases and poor management conditions than exotic chickens. Hence, cross breeding should be used to combine these economical important traits of exotic and indigenous chickens so as to create crossbreed chickens having good productive, reproductive and tropic environment resisting traits.

\section{References}

[1] CSA (Central Statistical Agency) 2020/21. Agricultural Sample Survey 2020/21. Report On Livestock and Livestock Characteristics. Volume II. Statistical Bulletin 589. Addis Ababa, Ethiopia.

[2] Demeke S. (2007). Suitability of hay-box brooding technology to rural household poultry production system, Lives. Res. Rural Dev., 19 (1).

[3] Yami, A. (1995). Poultry production in Ethiopia, World's Poult. Sci. J., 51: 197-201.

[4] Tadelle, D., Alemu Y. and Peters, K. J. (2000). Indigenous chicken in Ethiopia: Genetic potential and attempts at improvement, World Poult. Sci. J., 56: 45-54.

[5] Alemu, D., Degefe, T., Ferede, S., Nzietcheung S. and Roy, D. (2009). Overview and background paper on Ethiopia's poultry sector: Relevance for HPAI research in Ethiopia. A Collaborative Research Project, Africa/Indonesia Team Working Paper No, 1, International Food Policy Research Institute (IFPRI), International Livestock Research Institute (ILRI), Royal Veterinary College (RVC), Washington, DC., USA., pp: 709-715.

[6] Demeke, S. (2008). Poultry Sector Country Review, FAO, Rome, Italy.

[7] Halima, H. (2007). Phenotypic and Genetic Characterization of Indigenous Chicken Populations in Northwest Ethiopia, $\mathrm{PhD}$ Thesis; University of the Free State, Bloemfontein, South Africa, p. 186.

[8] Bogale, K. (2008). In situ characterization of local chicken eco-type for functional traits and production system in Fogera district, Amahara regional state, M.Sc. Thesis submitted to the department of animal science school of graduate studies, Haramaya University, pp: 107.

[9] Nigussie D. (2011). Breeding programs for indigenous chicken in Ethiopia, Analysis of diversity in production systems and chicken populations, PhD. Thesis submitted in fulfillment of the requirements for the degree of doctor at Wageningen University Netherlands, 148pp.

[10] Abebe, H. (1992). Terminal report on the comparative evaluation of indigenous chicken in the Hararge administrative region and their crosses with the single combed White leghorn report, Alemaya University of Agriculture, Ethiopia, pp: 22-27. 
[11] Solomon, D. (2003). Growth Performance of Local and White Leg Horne chicken under scavenging and intensive System of management in Ethiopia, Jimma College of Agriculture, Jimma, Ethiopia.

[12] Bekele, F., Adnoy, T., Gjoen, HM., Kathle, J. and Abebe, G. (2010). Production performance of dual-purpose crosses of two indigenous with two exotic chicken breeds in sub-tropical environment, Int. J. Poult. Sci., 9 (7): 702-710.

[13] Nigussie, D., Vander WE. and Johan A. M. (2010). Genetic and phenotypic parameter estimates for body weights and egg production in Horro chicken of Ethiopia, Submitted to Trop Anim. Health Prod, Animal breeding and genomics centre, Wageningen University Netherlands 14 July 2010, 46: 11-23.

[14] Habte, M., Ameha, N., \& Demeke, S. (2013). Production Performance of Local and Exotic Breeds of Chicken at Rural Household Level in NoleKabbaWoreda, Western Wollega, Ethiopia, African Journal of Agricultural Research, 8 (11): 1014-1021.

[15] Mekonnen G. (2007). Characterization of Smallholder Poultry Production and Marketing System of Dale, Wonsho and Loka Abaya Weredas of Southern Ethiopia, Msc. Thesis presented to the School of Graduate Studies of Hawassa University Hawassa Ethiopia.

[16] Addisu, H. Hailu M. Zewdu W. (2013). Indigenous Chicken Production System and Breeding Practice in North Wollo, Amhara Region, Ethiopia, Poult Fish Wildl Sci 1: 108.

[17] Tadelle, D., Alemu, Y. and Peters, K. (2003). Village chicken production systems in Ethiopia: Use patterns and performance evaluation and chicken products and socio-economic functions of chicken, Livestock Research for Rural Development (Available from http:// www.lrrd.org/lrrd15/1/tadeb151.htm) (Accessed on 1 September 2010), evaluation of Rhode Island Red (RIR) and local pp: 15: 1 .

[18] Kidane, H. M. (1980). Performance of F1cross breeds, Wolaita agricultural development unit. Animal husbandry and breeding. Wolaita Sodo, Ethiopia. Bulletin No., 4: 33.

[19] Brannang, E. and Person, S. (1990). Ethiopian animal husbandry and Breeding in the tropics and sub- tropics, Humboldt University of Berlin, Germany. Uppsala, Sweden, pp: 127.

[20] Negussie, D. and Ogle, B. (1999). On farm evaluation of Rhode Island Red (RIR) and local chickens under different management regimes in the high land of Ethiopia, M.Sc. Thesis, Swedish University of Agricultural Science, Uppsala, Sweden.

[21] CSA. Agricultural sample survey (2010/11). Volume 2: Report on livestock and livestock characteristics (prevent peasant holdings), Statistical Bulletin 505, Addis Ababa, February 2011, pp: 1-21. 2011.

[22] Tadelle, D. and Ogle, B. (2001). Village poultry production Systems in the central highlands of Ethiopia, Trop. Anim. Hlth. Proceeding, 33: 521-537.

[23] Nebiyu, Y., Brhan, T. \& Kelay, B. (2013). Characterization of Village Chicken Production Performance under Scavenging System in Halaba District of Southern Ethiopia, Ethiop. Vet. J., 17 (1): 69-80.

[24] Solomon, Z., Binyam, K., Bilatu, A. \& Ferede, A. (2013). Village Chicken Production Systems in Metekel Zone,
Northwest Ethiopia, Wudpecker Journal of Agricultural Research, 2 (9): 256-262.

[25] Wondu, M., Mehiret, M. \& Berhan, T. (2013). Characterization of Urban Poultry Production System in Northern Gondar, Amhara Regional State, Ethiopia, Agriculture and Biology Journal of north America Issn Print: 2151-7517.

[26] Worku, Z., Melesse, A. \& T/Giorgis, T. (2012). Assessment of Village chicken production system and the performance of local chicken population in West Amhara Region of Ethiopia, Journal of Animal Production Advances, 2 (4): 199-207.

[27] Meseret M. (2010). Characterization of Village Chicken Production and Marketing System", M.Sc. Thesis Submitted to the Department of Animal Science, Jimma University, College of Agriculture and Veterinary Medicine, School of Graduate Studies, 110pp.

[28] Demeke, S. (2004). Egg production performance of local and White Leghorn hens under intensive and rural household conditions in Ethiopia, Livestock Res. Rural Dev., Vol. 16.

[29] Tomas, M., Niraj, K., Berihu, G., Etsay, K. and Tsegay, T. (2017). Performance of Bovans Brown chickens under intensive and backyard management system in Mekelle, Ethiopia, Ethiopian Journal of Veterinary Science and Animal Production (EJVSAP) 1 (1): 73-80.

[30] Desalew, T., Harpal S., Ashenafi, M., Wondimeneh, E. and Tadelle D. (2013). Study on productive performances and egg quality traits of exotic chickens under village production system in East Shewa, Ethiopia, African Journal of Agricultural Research, Vol. 8 (13), pp 1123-1128. 2013.

[31] Abraham, L. and Yayneshet, T. (2010). Performance of exotic and indigenous poultry breeds managed by smallholder farmers in northern Ethiopia, Livestock Res. Rural Dev., Vol. 22.

[32] Jacob, J., Wilson, H., Miles, R., Butcher, G. and Mather, B. (1998). Factors Affecting Egg Production in Backyard Chicken fact sheet PS-35, Institute of Food and Agricultural Sciences, University of Florida.

[33] Alganesh, T. Matewos, B. and Gizaw, K. (2003). Survey on traditional livestock production system. Proceeding 11th Annual Conference of Ethiopian Society of Animal production, Addis Ababa, Ethiopia, August 28-30, 2003. pp. 141-150.

[34] Desalew, T. (2012). Management practices, productive performances and egg quality traits of exotic chickens under village production system in east shewa, Ethiopia, M.Sc Thesis Submitted to the School of Graduate Studies of Addis Ababa University.

[35] Alem, T. (2014). Production and reproduction performance of rural poultry in lowland and midland agro-ecological zones of central Tigray, Northern Ethiopia, Afr. J. Agric. Res., 9: 35313539 .

[36] Geleta, T., Leta S., and Bekana E. (2013). Production performance of Fayoumi chickens under intensive management condition of Adami Tulu research center, Int. J. Livestock Prod., 4: 172-176.

[37] Kebede, H., Urge M., and Kebede, K. (2014). Effect of replacing maize with malted barley grain on fertility, hatchability, embryonic mortality and chick quality of white leghorn layers, Global J. Poult. Farming Vaccination, 2: 121-125. 